\title{
Interferon patent contested
}

\section{Boston and London}

BIOGEN NV has scored a provisional victory in the competition to market alpha (leukocyte) interferon. The European $\mathrm{Pa}$ tent Office has formally notified the biotechnology company, based in Cambridge, Massachusetts, and Geneva, Switzerland, that it will receive a product patent for its alpha interferon synthesized by recombinant DNA technology. The patent could bring Biogen and its licensee, Schering-Plough Corporation, commercial dominance in selling alpha interferon (trademarked Intron) in the important European pharmaceutical market.

Genentech, the South San Francisco biotechnology company, is crying foul, and plans vigorously to challenge the European Patent Office's action during the nine month appeals period after the patent's issue, which may yet be some months away. According to Genentech and its partner F. Hoffman LaRoche and Co., it would be wrong for Biogen to receive a patent covering production of any cloned alphainterferon in bacteria, yeast or mammalian cells

Biogen's patent application refers to recombinant DNA molecules and processes for the production of human interferon alpha-like polypeptides. The initial research, carried out at the University of Zurich, led to a paper in Nature (284, $316 ; 1980)$ describing the production in Escherichia coli of a polypeptide with interferon activity. But according to Genentech the patent related to this work should only cover the cloning and production of a precursor to alpha inteferon, not the mature interferon that is biologically cleaved from it. Genentech's work was published in Nature six months after Biogen's $(287,411 ; 1980)$ and its patent application, filed six months after Biogen's, claims priority for producing mature interferon.

Biogen notes that this will be the first patent issued for a commercially significant product from the biotechnology industry. It is aggressively seeking issue of a US patent, and plans quickly to enforce its exclusive rights to European manufacture and sales. Biogen vice-president Peter Feinstein says that the company will soon inform its competitors that they must cease European production, although it is unlikely that any notice will be taken of such a demand.

Schering-Plough has sought regulatory approval for two uses of alpha interferon in cancer therapy. Last year multiple myeloma, malignant melanoma and Kaposi's sarcoma were among the conditions where it was said to have therapeutic potential. The extensive clinical trials and regulatory hurdles that must be passed for approval of new cancer treatments will probably prevent the drug - no matter who is making it - from reaching the market for at least another year or two.

The immediate beneficiaries of alpha interferon will be patent lawyers, who are now rubbing their hands with glee at the prospect of what is likely to be a prolonged case. And with Biogen also seeking patent protection for beta and gamma interferons, there is likely to be much more to come. Christopher Earl \& Tim Beardsley

\section{More Antarctic chill for Japan}

\section{Tokyo}

JAPAN is to increase its stake in Antarctica with the building of a third permanent research station for the national polar research institute (NIPR). The go-ahead for the new base came directly from Antarctica after ten members of the 25th summer Antarctic expedition, accompanied by NIPR head Takeshi Nagata, reached the proposed site in four snowmobiles and a helicopter last week.

The new research station will be built close to the now abandoned Belgian base of Roi Baudouin at the foot of 3,180 Mt Ser Rondane (71.3S, 24.4E), $100 \mathrm{~km}$ inland from Breid Bay and $650 \mathrm{~km}$ from Japan's large Showa base on Ongul Island, Lutzow Holm Bay. Weather permitting, use of the base will begin in the next Antarctic summer. Seven or eight scientists will soon be able to overwinter, adding to the fifty-five Japanese already in permanent occupation at the Showa and smaller Mizuno bases.

Funds for the new station will be provided by an increase of NIPR's annual budget to 3,300 million yen (\$14 million). Tatsuro Matsuda, head of NIPR's research division, stressed that the new station, like those already established, will be used purely for academic research. Meteorology, glaciology, geology and cartography will be the principal areas of investigation, together with participation in the auroral and middle atmosphere study programme for which rockets and balloons are launched from the Showa base. Despite increasing pressure from the commercial exploitation of Antarctica, NIPR has no intention of undertaking any estimates of potential mineral reserves, said Dr Matsuda.

Within Japan itself, most pressure for the commercial exploitation of Antarctic resources comes from the fishing industry, now by far the largest in the world. As twothirds of the catch comes from foreign fishing grounds, many of them within other nations' 200-mile economic zones, the advantages of exploiting Antarctic krill are great. Alun Anderson
Paranormality Koestler chair
for Edinburgh

ClAIRVOYANTS, spoonbenders and others boasting paranormal talents will shortly be needed for research to be conducted at the University of Edinburgh. The university is to become the first in Britain with a professorial chair in parapsychology, and the successful applicant could be appointed as early as September.

The chair is supported from the estate of the late Arthur Koestler, who committed suicide with his wife last year (see Nature 302, 93; 1983). Koestler became increasingly preoccupied with mystical matters toward the end of his life, and left a sum

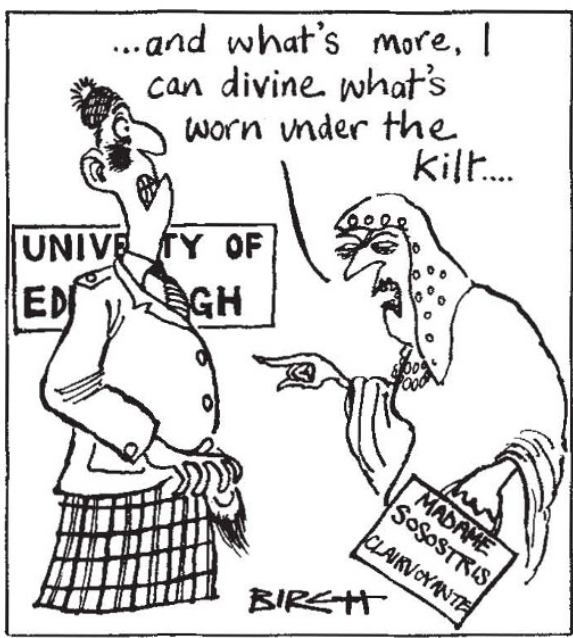

believed to be in excess of $£ 500,000$ to make permanent provision for a chair. The Koestler Foundation has pledged the interest from a similar sum to support a research programme.

Executors of Koestler's will had to choose between three serious contenders for the endowment - Edinburgh, City University, London, and the University of Wales. Edinburgh was chosen, according to Dr John Beloff, one of Koestler's executors and a member of the psychology department at Edinburgh, because it was able to offer the best facilities: several rooms will be made available for the new professor in the psychology department. But Beloff will not himself be applying for the post, although he does carry out research in the field.

Announcing the establishment of the chair, Dr John Burnett, principal of the University of Edinburgh, said that after widespread consultation it was clear there was overwhelming support within the university for the idea. The new professor will carry out research into "the capacity attributed to some individuals to interact with their external environment by means other than the recognized channels"'. Dr Burnett said that the investigations were likely to lead to new knowledge, whatever their outcome.

Tim Beardsley 